\title{
An Analysis of Environmental Dimensions Affected in Adoption of Hydrogen Fuel Cell Vehicles: A Study in Shah ALAM Industrial AREA, Selangor
}

\author{
Rusinah Siron ${ }^{1}$, Tan Kwe Lu ${ }^{2}$ and Mohd Amin Tasripan ${ }^{2}$ \\ ${ }^{1}$ Graduate Business School, College of Graduate Studies, Universiti Tenaga Nasional, 43000 Kajang, Malaysia \\ ${ }^{2}$ Institute of Energy Policy and Research, Universiti Tenaga Nasional, 43000 Kajang, Malaysia, College of Foundation and General Studies, \\ Universiti Tenaga Nasional, 43000 Kajang, Malaysia
}

\begin{abstract}
The aim of the study is to identify the perceptions of respondents on environmental dimensions hat affected in adoption of hydrogen fuel cell vehicles. The study was conducted at Shah Alam industrial areas of Selangor, Malaysia, with the number of respondents are 120 respondents with various job positions that related with engineering and automobiles industry. The findings of the research shows that the dimensions of HFCV Internal Environmental total score of the items statement is 3.40 with the percentage of agreement in implementation is 3.72 percent, HFCV Environmental Information Systems shows that the total score of the items statement is 3.63 with the percentage of agreement on use to great extend is 42.5 percent, HFCV Cooperation with Customers shows that the total score of the items statement is 3.81 with the percentage of agreement on implementation is 44.2 percent. The findings on HFCV Eco Design shows that the total score of items statement is 4.02 with the percentage of agreement on implementation is 42.3 percent, HFCV Environmental Organizational Culture shows that the total score of the items statement is 3.37 with the percentage of agreement is 34.2 percent, HFCV Environmental Leadership shows that the total score of the items statement is 3.34 with the percentage of agreement is 48.2 percent. HFCV Proactive Green Innovation shows that the total score of items statement is 4.10 ahead of automobile got the highest mean score of 4.32 with the percentage of agreement is 41 percent. HFCV Environmental performance shows that the total score of the items statement is 3.87 with the percentage of agreement is 39 percent and the last environmental dimensions was HFCV Environmental Risks shows that the total score of the item statement is 4.00 with the percentage of agreement is 40 percent
\end{abstract}

\section{Introduction}

A hydrogen fuel cell vehicle is a type of electric vehicle that uses a fuel cell instead of a battery to power the car. Hydrogen cars are basically electric cars. They have electric motors that drive the wheels just like an electric cars but the difference lies in the battery. A hydrogen fuel cell creates a chemical reaction with the hydrogen that generates electricity, water and heat. Just like an electric car, there are no harmful exhaust emissions that can affect environment. But the continuous improvement on the management and behavioural dimensions of the HFCV manufacturers and users are needed to safe and secure the environment for the long term. The initiatives of HFCV management and behavioural dimensions that consists of HFCV internal environmental management, HFCV proactive in green management, HFCV environmental organizational culture, HFCV environmental leadership and HFCV environmental performance is in need to continuously care and cautions on the impact of environment in an adoption of HFCV.

\section{Literature review}

In the perspective of environmental impact, hydrogen fuel cells are a clean, reliable, quiet, and efficient sources of high-quality electric power. The hydrogen use as a fuel to drive an electrochemical process that produces electricity, with water and heat as the only by-products.

In the perspectives of environmental impact of hydrogen fuel cell vehicles, there is a few advantages of using hydrogen fuel cell as follows:

1) Converting hydrogen gas into electricity produces only water and heat as a product, meaning fuel cell vehicles did not create tailpipe pollution when they are driven

2) Hydrogen fuel cell vehicles combines the range and refuelling of conventional cars with the recreation and environmental benefits of driving on electricity.

\section{Research methodology}

\subsection{The research objective}


The research objective of the study is to identify the perceptions of the respondents on environment dimensions in adoption of hydrogen fuel cell vehicles in Malaysia.

\subsection{The Respondents}

The study was conducted at Shah Alam Industrial Area, Selangor. Shah Alam is the state capital of Selangor, Malaysia and situated within the Petaling District and a small portion of the neighbouring Klang District. It is located about 25 kilometres west of the country's capital, Kuala Lumpur. The respondents of the study was consists of employees at managerial and operation level in related industry as follows:

\begin{tabular}{lll}
\hline \hline Industry Category & $\begin{array}{l}\text { No of } \\
\text { industry }\end{array}$ & Respondents \\
\hline - Transportation equipment & 7 & 38 \\
$\quad$ manufacturing & & \\
- Automobile Industries & 2 & 43 \\
- Car sales and service centre & 15 & 22 \\
- Metal product manufacturing & 3 & 10 \\
- Machinery manufacturing & 4 & 7 \\
\hline \hline
\end{tabular}

\subsection{The research instrument and measurement}

The instrument and measurement of the questionnaire items was by use of "five-point scale from 1 to 5 ". The rating constructs in this study were in following:

\begin{tabular}{|c|c|}
\hline Measurement & Scales \\
\hline $\begin{array}{l}\text { 1. HFCV Internal Environmental } \\
\text { Management } \\
\text { Adopted (Source: Zhu et al; } \\
\text { Kenneth W. Green Jr and Pamela } \\
\text { J. Zelbst, 2012, and revised the } \\
\text { items to suit with the study } \\
\text { requirement. }\end{array}$ & $\begin{array}{l}\text { Five-point scale } \\
\text { (1 -not considering } \\
\text { it; } 2 \text { - planning to } \\
\text { consider it; } 3 \text { - } \\
\text { considering it } \\
\text { currently; } 4 \text { - } \\
\text { initiating } \\
\text { implementation; } 5 \text { - } \\
\text { implementing } \\
\text { successfully) }\end{array}$ \\
\hline $\begin{array}{l}\text { 2. HFCV Proactive Green } \\
\text { Innovation } \\
\text { Adopted (Source: O'Connor et al., } \\
\text { 2006; Chen YS et al. (2012) and } \\
\text { revised the items to suit the study } \\
\text { requirement. }\end{array}$ & $\begin{array}{l}\text { Five point Likert } \\
\text { scale } \\
(1-\text { strongly } \\
\text { disagree to } 5 \text { - } \\
\text { Strongly agree) }\end{array}$ \\
\hline $\begin{array}{l}\text { 3. HFCV Environment } \\
\text { Information Systems } \\
\text { Adopted (Source: Esty and } \\
\text { Winston, 2006, Kenneth W. } \\
\text { Green Jr and Pamela J. Zelbst } \\
\text { 2012, and revised the items to suit } \\
\text { with the study requirement. }\end{array}$ & $\begin{array}{l}\text { Five-point scale } \\
\text { (1-not used at all; } 5 \\
\text { - used to a great } \\
\text { extent) }\end{array}$ \\
\hline $\begin{array}{l}\text { 4. HFCV Cooperation with } \\
\text { customers } \\
\text { Adopted (Source: Zhu et al; } \\
\text { Kenneth W. Green Jr and Pamela } \\
\text { J. Zelbst, 2012, and revised the } \\
\text { items to suit with the study } \\
\text { requirement. }\end{array}$ & $\begin{array}{l}\text { Five-point scale } \\
\text { (1 -not considering } \\
\text { it; } 2 \text { - planning to } \\
\text { consider it; } 3 \text { - } \\
\text { considering it } \\
\text { currently; } 4 \text { - } \\
\text { initiating } \\
\text { implementation; 5- } \\
\text { implementing }\end{array}$ \\
\hline
\end{tabular}

\begin{tabular}{|c|c|}
\hline & successfully) \\
\hline $\begin{array}{l}\text { 5. HFCV Eco Design } \\
\text { Adopted (Source: Zhu et al; } \\
\text { Kenneth W. Green Jr and Pamela } \\
\text { J. Zelbst, 2012, and revised the } \\
\text { items to suit with the study } \\
\text { requirement. }\end{array}$ & $\begin{array}{l}\text { Five-point scale } \\
\text { (1-not considering } \\
\text { it; } 2 \text { - planning to } \\
\text { consider it; } 3- \\
\text { considering it } \\
\text { currently; } 4 \text { - } \\
\text { initiating } \\
\text { implementation; 5- } \\
\text { implementing } \\
\text { successfully) }\end{array}$ \\
\hline $\begin{array}{l}\text { 6. HFCV Environmental } \\
\text { Organizational Culture } \\
\text { Adopted (Source: Chen, 2011, } \\
\text { Chen et al. 2012) }\end{array}$ & $\begin{array}{l}\text { Five point Likert } \\
\text { scale } \\
(1-\text { strongly } \\
\text { disagree to } 5 \text { - } \\
\text { Strongly agree) }\end{array}$ \\
\hline $\begin{array}{l}\text { 7. HFCV Environmental } \\
\text { Leadership } \\
\text { Adopted (Source: Chen, 2011, } \\
\text { Chen et al. 2012) }\end{array}$ & $\begin{array}{l}\text { Five point Likert } \\
\text { scale } \\
(1-\text { strongly } \\
\text { disagree to } 5- \\
\text { Strongly agree }) \\
\end{array}$ \\
\hline $\begin{array}{l}\text { 8. HFCV Environmental } \\
\text { Performance } \\
\text { Adopted (Source: Zhu et al; } \\
\text { Kenneth W. Green Jr and Pamela } \\
\text { J. Zelbst, 2012, and revised the } \\
\text { items to suit with the study } \\
\text { requirement. }\end{array}$ & $\begin{array}{l}\text { Five point scale } \\
(1-\text { not at all; } 2-\text { a } \\
\text { little bit; } 3 \text { - to some } \\
\text { degree; } 4 \text { - relatively } \\
\text { significant; } 5 \text { - } \\
\text { significant }\end{array}$ \\
\hline $\begin{array}{l}\text { 9. HFCV Environmental Risks } \\
\text { Adopted (Source: } \\
\text { and Sonya Graci } \\
\text { downloading } \\
\text { http://green.hotelscombined.com) }\end{array}$ & $\begin{array}{l}\text { Five point Likert } \\
\text { scale } \\
(1-\text { strongly } \\
\text { disagree to } 5- \\
\text { Strongly agree }) \\
\end{array}$ \\
\hline
\end{tabular}

\subsection{Data analysis}

Data analysis used in this study was descriptive statistics with mean score and the percentage of the agreement for the assessment of respondent perception on items measurement.

\section{Research findings}

The result of the findings were presented accordingly based on the following:

Section A: Respondent Demographic Profile

\begin{tabular}{ll}
\hline \hline Job Title & Number \\
\hline - Plant Manager & 5 \\
- Operation Manager & 6 \\
- Purchasing Manager & 12 \\
- Logistics Manager & 8 \\
- Sales Manager & 15 \\
- Engineering Manager & 18 \\
- Industrial Waste Manager & 4 \\
- Supply Chain Manager & 6 \\
- Information Systems Manager & 7 \\
- Executives and Administrative Officer & 18 \\
- Technician & 21 \\
$\quad$ TOTAL & $\mathbf{1 2 0}$ \\
\hline \hline Industry Category & $\mathbf{N u m b e r}$ \\
\hline - Transportation equipment manufacturing & 7 \\
- Automobile Industries & 2 \\
- Car sales and service centre & 15 \\
- Metal product manufacturing & 3 \\
- Machinery manufacturing & 4 \\
\hline \hline
\end{tabular}


The number of respondents involved in the study was 120 respondents. Demographic profile for respondents in Shah Alam Industrial Area, Selangor was summarized in majority of respondents as per shown in Table 1.

Table 1. Summary of demographic profile of respondents

\begin{tabular}{llll} 
No & $\begin{array}{l}\text { Demographic } \\
\text { Variable }\end{array}$ & Majority & $\begin{array}{l}\text { Percentage } \\
(\%)\end{array}$ \\
\hline $\mathbf{1}$ & Gender & Male & 68 \\
\hline $\mathbf{2}$ & Citizen & Citizen & 100.0 \\
\hline $\mathbf{3}$ & Age & 31- 45 Years & 65 \\
\hline $\mathbf{4}$ & Race & Malay & 75 \\
\hline $\mathbf{5}$ & Religion & Muslim & 80 \\
\hline $\mathbf{6}$ & Education Level & Diploma/Degree & 58 \\
\hline $\mathbf{7}$ & Job Category & Administration & 31.8 \\
\hline $\mathbf{8}$ & Monthly Income & $\begin{array}{l}\text { RM 1,001 - RM } \\
5,000\end{array}$ & 81.2 \\
\hline \hline
\end{tabular}

Section B: The Findings of Variables

1) HFCV Internal Environmental Management

The findings on HFCV Internal Environmental Management is shown in Table 2.

Table 2. The mean score of hfcr internal environmental management

\begin{tabular}{|c|c|c|}
\hline $\begin{array}{l}\text { HFCV } \\
\text { Environmental } \\
\text { Management }\end{array}$ & $\begin{array}{l}\text { Mean } \\
\text { Score }\end{array}$ & $\begin{array}{l}\text { \% of Agreement } \\
\text { on } \\
\text { Implementation }\end{array}$ \\
\hline $\begin{array}{l}\text { - Commitment and support } \\
\text { of HFCV environmental } \\
\text { practices from top } \\
\text { management towards }\end{array}$ & 3.58 & $45 \%$ \\
\hline 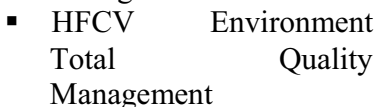 & 3.45 & $38 \%$ \\
\hline $\begin{array}{l}\text { - HFCV Environmental } \\
\text { compliance and auditing } \\
\text { program }\end{array}$ & 3.33 & $35 \%$ \\
\hline $\begin{array}{l}\text { - HFCV Environmental } \\
\text { Program Systems } \\
\end{array}$ & 3.25 & $30 \%$ \\
\hline - Total Score & 3.40 & $37.2 \%$ \\
\hline
\end{tabular}

The findings on HFCV Internal Environmental Management shows that the total score of the items statement is 3.40 with the percentage of agreement in implementation is 37.2 percent.

2) HFCV Environment Information Systems

The finding on HFCV Internal Environmental Management is shown in Table 3.

Table 3. The mean score of HFCV environmental information systems

\begin{tabular}{lll}
\hline \hline $\begin{array}{l}\text { HFCV Environment } \\
\text { Information Systems }\end{array}$ & $\begin{array}{l}\text { Mean } \\
\text { Score }\end{array}$ & $\begin{array}{l}\text { \% of Agreement } \\
\text { on use to great } \\
\text { extend }\end{array}$ \\
\hline $\begin{array}{l}\text { HFCV can reduce } \\
\text { transportation costs }\end{array}$ & $52 \%$ \\
- Tracking HFCV \\
$\begin{array}{l}\text { environmental information } \\
\text { (such as toxicity, energy }\end{array}$
\end{tabular}

encourage choices of car vehicles by consumers

- Improving decision $3.55 \quad 40 \%$ making by executives by highlighting sustainability issues

- Reducing energy $3.45 \quad 38 \%$

consumption and distribution of renewable energy

- Limiting carbon and other $3.35 \quad 32 \%$ emissions

\begin{tabular}{lll}
\hline - Total Score & 3.63 & $42.5 \%$
\end{tabular}

The findings on HFCV Environmental Information Systems shows that the total score of the items statement is 3.63 with the percentage of agreement on use to great extend is 42.5 percent.

3) HFCV Cooperation with Customers

The findings on HFCV Internal Environmental Management is shown in Table 4.

Table 4. The mean score of HFCV cooperation with customers

\begin{tabular}{|c|c|c|}
\hline $\begin{array}{l}\text { HFCV Cooperation with } \\
\text { Customers }\end{array}$ & $\begin{array}{l}\text { Mean } \\
\text { Score }\end{array}$ & $\begin{array}{l}\% \text { of } \\
\text { Agreement on } \\
\text { Implementation }\end{array}$ \\
\hline $\begin{array}{l}\text { - Cooperation with customers } \\
\text { for eco design of HFCV }\end{array}$ & 4.11 & $54 \%$ \\
\hline $\begin{array}{l}\text { - Cooperation with customers } \\
\text { for cleaner HFCV } \\
\text { production }\end{array}$ & 3.95 & $45 \%$ \\
\hline $\begin{array}{l}\text { - Cooperation with customers } \\
\text { for HFCV green } \\
\text { manufacturing }\end{array}$ & 3.65 & $40 \%$ \\
\hline $\begin{array}{l}\text { - Cooperation with customers } \\
\text { for using less energy during } \\
\text { HFCV product } \\
\text { transportation }\end{array}$ & 3.55 & $38 \%$ \\
\hline - Total Score & 3.81 & $44.2 \%$ \\
\hline
\end{tabular}

The findings on HFCV Cooperation with Customers shows that the total score of the items statement is 3.81 with the percentage of agreement on implementation is 44.2 percent.

4) HFCV Eco Design

The findings on HFCV Eco Design is shown in Table 5.

Table 5. The MEAN Score of HFCV eco design

\begin{tabular}{llll}
\hline \hline HFCV Eco Design & & $\begin{array}{l}\text { Mean } \\
\text { Score }\end{array}$ & $\begin{array}{l}\text { \% of Agreement } \\
\text { on Implementation }\end{array}$ \\
\hline - $\begin{array}{l}\text { Design of HFCV for } \\
\text { reduced consumption of }\end{array}$ & 4.21 & $48 \%$ \\
material/energy & & \\
- $\begin{array}{l}\text { Design of HFCV for reuse, } \\
\text { recycle, recovery of } \\
\text { material and/or component } \\
\text { parts }\end{array}$ & & \\
- $\begin{array}{l}\text { Design of HFCV to avoid } \\
\text { or reduce use of hazardous } \\
\text { and /or their manufacturing } \\
\text { process }\end{array}$ & & $3.01 \%$ \\
\hline - Total Score & $\mathbf{4 . 0 2}$ & $\mathbf{4 2 . 3 \%}$ \\
\hline \hline
\end{tabular}

The findings on HFCV Eco Design shows that the total score of items statement is 4.02 with the percentage of agreement on implementation is 42.3 percent. 
5) HFCV Environmental Organizational Culture

The findings on HFCV Environmental Organizational Culture is shown in Table 6.

Table 6. The mean score of HFCV environmental organizational culture

\begin{tabular}{|c|c|c|}
\hline $\begin{array}{l}\text { HFCV Environmental } \\
\text { Organizational Culture }\end{array}$ & $\begin{array}{l}\text { Mean } \\
\text { Score }\end{array}$ & \% of Agreement \\
\hline $\begin{array}{l}\text { - The company concerns the } \\
\text { knowledge } \\
\text { environmental } \\
\text { management } \\
\text { protection of HFCV }\end{array}$ & 3.55 & $45 \%$ \\
\hline $\begin{array}{l}\text { - The company concerns the } \\
\text { collaboration of } \\
\text { environmental } \\
\text { management and } \\
\text { protection of HFCV }\end{array}$ & 3.40 & $34 \%$ \\
\hline $\begin{array}{l}\text { - The company concerns of } \\
\text { environmental agreements } \\
\text { of HFCV }\end{array}$ & 3.30 & $30 \%$ \\
\hline $\begin{array}{l}\text { - The company concerns of } \\
\text { the responsiveness of } \\
\text { environmental } \\
\text { management and } \\
\text { protection of HFCV }\end{array}$ & 3.25 & $28 \%$ \\
\hline - Total Score & 3.37 & $34.2 \%$ \\
\hline
\end{tabular}

The findings on HFCV Environmental Organizational Culture shows that the total score of the items statement is 3.37 with the percentage of agreement is 34.2 percent.

6) HFCV Environmental Leadership

The findings on HFCV Environmental Leadership is shown in Table 7.

Table 7. The mean score of HFCV environmental leadership

\begin{tabular}{|c|c|c|}
\hline $\begin{array}{ll}\text { HFCV } & \text { Environmental } \\
\text { Leadership } & \\
\end{array}$ & $\begin{array}{l}\text { Mean } \\
\text { Score } \\
\end{array}$ & $\begin{array}{l}\% \text { of } \\
\text { Agreement }\end{array}$ \\
\hline $\begin{array}{l}\text { - The leaders within the } \\
\text { company inspire a shared } \\
\text { vision of the organization as } \\
\text { environmentally } \\
\text { sustainable, creating or } \\
\text { maintaining green values } \\
\text { throughout the company }\end{array}$ & 3.55 & $58 \%$ \\
\hline $\begin{array}{l}\text { - The leaders within the } \\
\text { company utilize well- } \\
\text { developed approaches to } \\
\text { environmental management } \\
\text { which generally centre } \\
\text { around a program } \\
\text { customized to the } \\
\text { company's specific business } \\
\text { and market }\end{array}$ & 3.40 & $50 \%$ \\
\hline $\begin{array}{l}\text { - The leaders within the } \\
\text { company create } \\
\text { partnerships with the } \\
\text { company's stakeholders to } \\
\text { solve environmental } \\
\text { problems and to accomplish } \\
\text { environmental goals }\end{array}$ & 3.33 & $45 \%$ \\
\hline $\begin{array}{l}\text { - The leaders within the } \\
\text { company can take on the } \\
\text { responsibility of } \\
\text { environmental education } \\
\text { with the intent of engaging }\end{array}$ & 3.10 & $40 \%$ \\
\hline
\end{tabular}

employees in environmental management initiatives

\begin{tabular}{lcc}
\hline - Total Score & $\mathbf{3 . 3 4}$ & $\mathbf{4 8 . 2 \%}$ \\
\hline \hline The findings on HFCV Environmental Leadership shows that
\end{tabular}
total score of the items statement is 3.34 with the percentage of agreement is 48.2 percent.

7) HFCV Proactive Green Innovation

The findings on HFCV Proactive Green Innovation is shown in Table 8.

Table 8. The mean score of HFCV proactive green innovation

\begin{tabular}{|c|c|c|}
\hline $\begin{array}{l}\text { HFCV Proactive Green } \\
\text { Innovation }\end{array}$ & $\begin{array}{l}\text { Mean } \\
\text { Score }\end{array}$ & $\begin{array}{l}\text { \% of } \\
\text { Agreement }\end{array}$ \\
\hline $\begin{array}{l}\text { - The company often undertakes } \\
\text { active environment-related } \\
\text { innovation in order to take } \\
\text { initiatives new practices or } \\
\text { products ahead of automobiles } \\
\text { industry }\end{array}$ & 4.32 & $45 \%$ \\
\hline $\begin{array}{l}\text { - The company actively commit } \\
\text { to continuously invest } \\
\text { resources in green innovations } \\
\text { to successfully seize } \\
\text { opportunities and to lead in } \\
\text { the market }\end{array}$ & 4.05 & $40 \%$ \\
\hline $\begin{array}{l}\text { - The company actively } \\
\text { improve manufacturing } \\
\text { processes to reuse, recycle, } \\
\text { and reduce materials to } \\
\text { decrease cost }\end{array}$ & 3.95 & $38 \%$ \\
\hline - Total Score & 4.10 & $41 \%$ \\
\hline
\end{tabular}

The findings on HFCV Proactive Green Innovation shows that the total score of items statement is 4.10 ahead of automobile got the highest mean score of 4.32 with the percentage of agreement is 41 percent.

8) HFCV Environmental Performance

The findings on HFCV Environmental Performance is shown in Table 9.

Table 9. The mean score of HFCV environmental performance

\begin{tabular}{lll}
\hline \hline $\begin{array}{l}\text { HFCV Environmental } \\
\text { Performance }\end{array}$ & $\begin{array}{l}\text { Mean } \\
\text { Score }\end{array}$ & $\begin{array}{l}\text { \% of } \\
\text { Agreement on } \\
\text { Significant }\end{array}$ \\
\hline - Reduction of air emission & 4.11 & $48 \%$ \\
- Reduction of effluent waste & 4.05 & $45 \%$ \\
- Reduction of solid waste \\
- Decrease in consumption \\
$\quad \begin{array}{l}\text { for hazardous/harmful/toxic } \\
\text { materials in frequency for }\end{array}$ & 3.85 & $38 \%$ \\
- Decrease in \\
$\begin{array}{l}\text { environmental accidents } \\
\text { Improvement in and } \\
\text { environmental situation }\end{array}$ & 3.65 & $28 \%$ \\
\hline - Total Score & $\mathbf{3 . 8 7}$ & $\mathbf{3 9 \%}$ \\
\hline
\end{tabular}

The findings on HFCV Environmental Performance shows that the total score of the items statement is 3.87 with the percentage of agreement is 39 percent.

9) HFCV Environmental Risks

The findings on HFCV Environmental Risks is shown in Table 10. 
Table 10. The mean score of HFCV environmental risks

\begin{tabular}{lll}
\hline \hline HFCV Environmental Risks & $\begin{array}{l}\text { Mean } \\
\text { score }\end{array}$ & $\begin{array}{l}\text { \% of } \\
\text { Agreement }\end{array}$ \\
\hline - Water and land & 4.21 & $45 \%$ \\
$\begin{array}{l}\text { Contamination } \\
\text { - Air and noise pollution }\end{array}$ & 4.00 & $42 \%$ \\
- Waste management & 3.98 & $38 \%$ \\
- Supply chain environmental & 3.84 & $35 \%$ \\
$\quad$ practices & & \\
\hline - Total Score & $\mathbf{4 . 0 0}$ & $\mathbf{4 0 \%}$ \\
\hline
\end{tabular}

The findings on HFCV Environmental Risks shows that the total score of the items statement is 4.00 with the percentage of agreement is 40 percent.

\section{Recommendation and conclusions}

\subsection{Recommendation}

Based on the study findings, the following recommendations to strengthen the environmental impact positively towards the adoption of HFCV are as follows:

\footnotetext{
1. HFCV Internal Environmental Management

- The top management should give full commitment on internal environmental management that can encourage proactive action and productive output on internal assessment and management of HFCV.

2. HFCV Environment Information Systems

- Provide information effectively and efficiently in HFCV

3. HFCV Cooperation with Customers

- The HFCV management should cooperate with customers in eco design, cleaner production, green product design and using less energy.

4. HFCV Eco Design

- The initiatives of designing the products that can reduced consumption of material and energy for reuse, recovery of material and recycle the component or material in HFCV

5. HFCV Environmental Organizational Culture

- The company that involve with HFCV must be concern on knowledge of environmental management, environmental agreements, responsiveness and the vision of environmental issues of HFCV.

6. HFCV Environmental Leadership

- The leaders in the organization that involves in HFCV adoption should be motivated to inspire a shared vision on environmental issues.

7. HFCV Proactive Green Innovation

- The management should be active in environment-related
}

innovation in order to take initiatives for HFCV to be
ahead than other vehicles.
HFCV Environmental Performance
The initiatives to reduce of air emissions, effluent waste,
solid waste and the decrease in consumption for
hazardous and harmful materials should be efficient.
HFCV Environmental Risks
Risk minimization is now viewed as increasingly
intertwined with good corporate social responsibility and
governance.

\section{Conclusion}

Based on the findings, it indicates that the environmental dimensions in adoption of HFCV could generate many constraint and benefits of the HFCV success in future. This study verifies the issues of environment that need to be in precaution on action of HFCV implementation.

\section{References}

1. Chen, Y.S. Green Organizational Identity: Sources and Consequences. Management Decision, 49, 3, pp. 384-404, (2011).

2. Chen, Y.S, Chang, C.H, Wu,F.S. Origin of Green Innovations: The Differences between Proactive and Reactive Green Innovation. Management Decision, 50, 3, pp. 368-398, (2012).

3. Esty, D and Winston, A. Green to Gold: How Smart Companies Use Environmental Strategy to Innovate, Create Value, and Build Competitive Advantage, Yale University Press, New Haven, CT, (2006).

4. Green Jr. K.W., Zelbst, P.J. Meacham, J. and Bhadauria V.S. Green Supply Chain Management Practies: Impact on Performance. Supply Chain Management: An International Journal, 17/3, pp. 290-305, (2012).

5. Graci, S. and Kuehnel, Jaqueline. How to increase your bottom line by going green. Downloading@ http://green.hotelscombined.com

6. Zhu, Q.,Sarkis, J. and Lai, K. Confirmation of a Measurement model for green supply chain management practices implementation. International Journal of Production Economics, 111, 2, pp. 261-73. (2008). 